\section{Uma polícia para o século XXI: comentário sobre o artigo de Minayo e Adorno}

A Police Force for the 21st Century: comments on the article by Minayo and Adorno

Ignácio Cano ${ }^{2}$

Os autores discutem os limites da organização policial, no Brasil e no mundo, à luz das mudanças históricas nos conceitos de risco e segurança. Dessas mudanças resultaria a necessidade de profundas alterações do modelo de polícia, com o objetivo de ajustá-lo à realidade atual. Na verdade, suas análises sobre as inadequações do modelo policial atual no país são bem abrangentes e vão além desses dois conceitos inicialmente considerados.

Como os autores nos lembram, risco é uma noção central para entender o mundo contemporâneo. Se em economia, e em outras áreas, risco é um conceito positivo associado à inovação $\mathrm{e}$ à obtenção de lucros, em epidemiologia ele é a base de um raciocínio preventivo que tem como meta reduzir a morbimortalidade. A pergunta básica a ser respondida, então, é sobre o que podemos mudar na nossa conduta para que um número menor de pessoas seja vítima de agravos à saúde. A resposta é obtida através de cálcu- los da probabilidade de doença e morte associadas às diversas opções de vida.

O resultado dessa nova visão de mundo é contraditório. Se a reflexão sobre o risco pode minimizar as chances de sofrer algum mal, ela pode também nos deixar instalados no temor e na ansiedade, na medida em que os avanços científicos nos revelam a infinidade dos perigos à nossa espreita, antes ignorados. Para alguns autores, a nossa era se define justamente pela ubiquidade do medo ${ }^{1}$, um medo difuso, um malestar universal. Nada exemplifica melhor o medo contemporâneo do que o terrorismo. A cada certo tempo, uma bomba explode em algum lugar do mundo e causa vítimas em lugares localizados a milhares de quilômetros daquele onde o conflito se originou. Assim, no mundo globalizado, todos estamos sujeitos a um risco que talvez não compreendamos plenamente, mas que aparentemente compartilhamos.

Como Giddens ${ }^{2}$ destaca, a nossa percepção do risco não corresponde ao risco real. A expectativa de vida do ser humano nunca foi tão longa, a despeito, ou talvez como resultado, da consciência dos múltiplos perigos que cercam sua vida. O mundo não é hoje mais perigoso, somos nós que o percebemos como tal.

Paralelamente a essa expansão da noção do risco, o conceito de segurança, seu antagonista natural, conquista também novos territórios. Discute-se não mais apenas a segurança dos Estados, mas a dos indivíduos. E não só contra a ameaça de morte, doença ou perda de propriedades, mas contra tudo o que colocar em risco a nossa segurança ontológica ${ }^{2}$, isto é, a ordem e a continuidade da nossa experiência no mundo. Nessa linha, o PNUD (Programa das Nações Unidas para o Desenvolvimento) define o termo "segurança humana" como liberação da necessidade e do temor, uma proposta tão abrangente como difícil de cumprir. Poder-se-ia dizer que o ser humano, atormentado pelos riscos que percebe, tornou-se cada vez mais ambicioso nas suas aspirações de segurança.

Certamente, essa evolução no conceito de segurança possui impactos na missão que a polícia desenvolve. Uma das transformações mais significativas é a nova visão da segurança como uma

${ }^{2}$ Departamento de Ciências Sociais, Centro de Ciências Sociais, Universidade do Estado do Rio de Janeiro. icano@openlink.com.br 
gestão dos riscos. Nela podemos distinguir dois componentes centrais. O primeiro é que o risco, por definição, não pode ser eliminado, tão somente minimizado. Daí se deriva justamente a necessidade da gestão. Assim, uma corporação de segurança que tomasse como missão aniquilar todas as fontes de insegurança teria o mesmo futuro que uma política de saúde que se propusesse acabar definitivamente com a mortalidade. O segundo elemento é que os gestores de segurança modernos assumem que devem cuidar não apenas do risco objetivo, mensurado através de taxas de vitimização, mas também do risco subjetivo, relativo à percepção dos cidadãos. Não basta mostrar que a incidência criminal é reduzida, é preciso que as pessoas se sintam seguras e o gestor da segurança não pode mais pretender que esse assunto não seja da sua competência.

Os autores argumentam, com razão, que a transformação na compreensão da segurança e do risco requer uma mudança do mandato policial, que se torna ampliado e mais complexo. Entretanto, essa evolução é também acompanhada pelo surgimento de novos atores com responsabilidade na produção da segurança, começando pelos próprios indivíduos, como assinala a Constituição Federal, até chegar nos municípios, nas organizações não governamentais e no governo federal. Assim, a segurança não é mais, se foi alguma vez, um serviço entregue pela polícia à população, mas construído em conjunto com ela. O conceito dominante é o da coprodução da segurança entre vários atores. Em outras palavras, se o fardo da segurança ganhou muito peso, existem agora outros atores que podem ajudar à polícia a carregá-lo.

Talvez a contribuição mais importante do trabalho de Minayo e Adorno é a sua reflexão do policial como produtor e consumidor simultâneo da segurança que ele ajuda a produzir. Com efeito, o policial compromete sua própria segurança para garantir a dos outros e paga um elevado preço por isso. O artigo enumera as diversas moedas em que este alto preço é cobrado: risco de morte nos confrontos armados, estresse pós-traumático, ideações suicidas, divórcio, dependência química e outros sinais de esgarçamento individual, familiar e social.

A ideia do sacrifício do policial em prol do coletivo se encaixa perfeitamente no ethos policial que pode ser observado, por exemplo, nos regulamentos disciplinares das polícias militares brasileiras $^{3}$. A imagem do policial que se depreende de tais regulamentos é a de um herói. Inclusive, vários deles exigem explicitamente que o agente arrisque a vida para cumprir sua missão. Entretanto, o modelo do policial herói é uma armadilha, que pode chegar a ser fatal, tanto para os policiais quanto para a sociedade. $\mathrm{O}$ caso extremo é o do policial guerreiro, estimulado a combater a qualquer custo o inimigo interno, contemporaneamente encarnado na figura do narcotraficante, com altos custos para as comunidades (mortes em confronto, violações aos direitos humanos, etc.) e para ele mesmo, conforme os agravos à sua saúde mencionados acima.

A contraproposta é simples. O policial, como gestor da segurança, deve começar por cuidar da sua própria. A organização policial e a sociedade devem garantir a proteção dos agentes de segurança pública não apenas por motivos de justiça, mas também de eficácia. Policiais que sintam seguros, com mais coletes e menos fuzis, serão muito mais capazes de prover segurança do que aqueles que temem constantemente pela vida. A segurança coletiva não pode ser obtida negligenciando a dos agentes da lei, sob a cruel desculpa da sua suposta vocação para o heroísmo. Como os anúncios de segurança nos aviões comerciais não se cansam de repetir, em caso de despressurização é preciso colocar a máscara de oxigênio em si mesmo para, só depois, assistir a terceiros.

Outro traço da imagem do policial que também se depreende dos regulamentos disciplinares é a de um super-herói moral, a quem qualquer pequeno deslize está vedado (mentir, beber álcool, gerar dívidas, etc.), inclusive na sua vida privada. Desse modo, a vida pessoal dos policiais passa a ser supervisionada e controlada pela corporação. Longe de conseguir produzir super-heróis morais de carne e osso, estas exigências resultam em policiais indefesos perante os superiores hierárquicos, que podem puni-los a qualquer momento e por qualquer razão, no isolamento dos agentes em relação à sociedade, composta por indivíduos cheios de 'fraquezas' que poderiam contaminá-los, e na deslegitimação de um sistema disciplinar que estabelece normas impossíveis de serem cumpridas na sua totalidade.

Por outro lado, o novo paradigma policial a ser criado deve oferecer aos agentes não apenas proteção, mas também a possibilidade de participar ativamente na produção da segurança, independentemente da patente ou da função. O paradigma ainda vigente, particularmente nas polícias militares, contempla um modelo de praça como alguém que deve obedecer sem pensar, muito menos debater. Muitos regulamentos disciplinares penalizam explicitamente a divulgação, por parte dos policiais, de informações ou opini- 
ões sobre segurança pública. A rigidez hierárquica e a tradição de isolamento institucional contribuem a reforçar o mesmo cenário. De novo, o modelo atual não é apenas injusto, por antidemocrático, mas também ineficaz para as metas que persegue. A $1^{\text {a }}$ Conferência Nacional de Segurança Pública celebrada em 2009 mostrou que as bases das pirâmides policiais têm contribuições significativas a fazer, até agora reprimidas, para a formulação das políticas de segurança. A elevação do nível educacional das novas promoções de policiais no país, inclusive nos escalões inferiores, aumenta a pressão para que seja concedido a eles um papel mais ativo na gestão da segurança.

Como já foi dito, o policial se caracteriza por ser ao mesmo tempo produtor e consumidor de segurança. Da mesma forma, ele também, simultaneamente, garante os direitos dos cidadãos e é um cidadão que espera usufruir esses mesmos direitos. A construção da segurança democrática deve começar pelos quartéis, pois não será possível implantar uma segurança pública democrática sem a participação ativa dos agentes da lei.

\section{Referências}

1. Bauman Z. Medo Líquido. Rio de Janeiro: Jorge Zahar; 2008.

2. Giddens A. As conseqüências da modernidade. São Paulo: Unesp; 1991.

3. Cano I, Duarte T. Análise Comparativa das Legislações Disciplinares das Corporações de Segurança Pública: uma proposta de Matriz de Lei Disciplinar para o Brasil. Brasília: SENASP; 2012. (no prelo) 